\section{Canada's nuclear visitor}

"THERE are thousands of manmade objects in space. I suppose roughly half of them belong to the Russians and the other half to the Americans..... I know there are things up there. I know they are going to fall someday, but $I$ don't want to hear about it until it looks as though they are going to fall in my country. When you hear that, call me again!"

Such was the breezy comment of Canadian Prime Minister Pierre Trudeau on the crash, or, to quote Montreal Radio, "unplanned re-entry" of Kosmos-954. This attitude seems typical of the understatement with which all parties concerned have treated the first cosmonuclear disaster, an attitude which Pravda described as "realistic" and "undoubtedly due to the climate of international detente".

Fortunately for the cheer-merchants, the errant satellite descended in an area where, according to Colonel Donald Davidson who led the search team "there is no specific indication" of people save "the odd trapper or trapline ... a few solitary souls who normally work the area". The specific location of the debris " $12.8 \mathrm{~km}$ northwest of the landing strip" about $300 \mathrm{~km}$ from Baker Lake and $1,500 \mathrm{~km}$ northwest of Edmonton brought home to the world at large that Canada had just abandoned the mile. Even the general vicinity of the impact was seized upon by the joke-makers ("Great Slave Lake, eh? Maybe it thought it was heading for the Gulag Archipelago!"). Even the fact that the satellite finally landed in an area with sufficient uranium deposits to give false readings on the search instruments was not without its special brand of irony.

But leaving aside both humour and grim speculation on the devastation which might have resulted had the

\section{US agencies to study links between saccharin and cancer}

SACCHARIN is to be investigated by the US Food and Drug Administration and the National Cancer Institute, who are to conduct an epidemiological study of 9,000 people in an attempt to determine whether there is a connection between saccharin and bladder cancer.

The dietary habits of 3,000 people diagnosed as having bladder cancer will be compared against those of a randomly-selected 6,000 controls. The study is expected to last 18 months, and to cost $\$ 1.3$ million.

Last November, Congress announced a moratorium on proposed legislation that would ban the use of saccharin satellite fallen further south, a number of questions remain unanswered. Why did debris reach the ground at all, when, according to Tass, the nuclear power unit was designed to be fully destroyed and bunnt on re-entry. And,

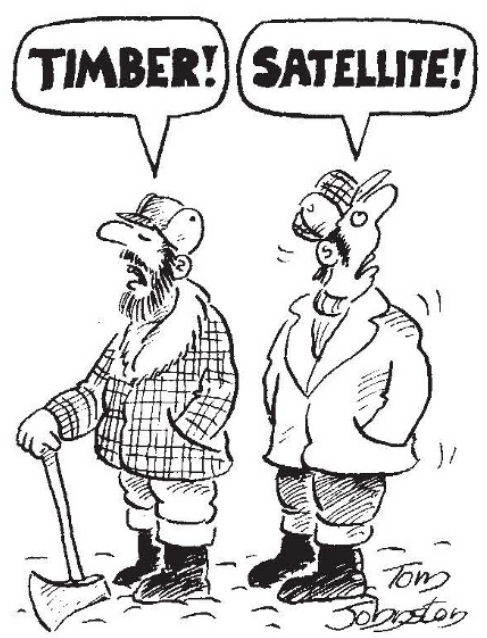

if the fail-safe construction of the craft was lacking in this respect, would such a burn-up have been, as claimed, without radiation hazard? How safe, indeed, is the debris? (The two members of the search team who found the impact crater have been removed to University Hospital, Edmonton, and the other members to the hospital in Yellowknife.)

More important, what is the procedure for notifying countries that a nuclear satellite may be about to fall? In spite of an opposition hammering, the Canadian Minister of Defence Danson and Secretary of State for External Affairs Jamieson seemed fairly content with the manner in which notification came largely through Washington. However, Canada

because of its suspected link with bladder cancer. Congress also agreed to allocate \$1 million for studies on the safety of saccharin, $\$ 750,000$ of which is for the epidemiological survey.

Congress's action followed the publication in October of a report on cancer tesîng technology and saccharin from its Office of Technology Assessment, which concluded that although there was evidence that saccharin is a potential cause of cancer in humans, there was no reliable quantitative estimates of the risk of saccharin to humans.

According to the OTA report, epidemiological studies of human experience carried out so far have not been sensitive enough to determine if saccharin is a carcinogen when injested. $\square$ is a somewhat special case, being a participant in the US Space Detection and Tracking System via the optical facilities at Cold Lake, Alberta, and St Margarets, New Brunswick. (Canada is also associated with the USA in the NORAD early warning air defence system. Although this relates primarily to manned aircraft attack.) In return for this contribution to the tracking system, Canada automatically receives from the USA all relevant data on space objects. Hence the routing of the warning via Washington is at worst only a slight blow to Canada's armour propre. What, however, would have been the procedure if some other target country were involved? Would the message always go via "hotline" to Washington, or perhaps via the nearest "major" power? What then would be, for example, Dublin's reaction to such a warning being routed via London?

International agreements already provide for the search and disposal of crashed space-craft-the craft is to be returned to its owner, the target country reimbursed for damage and search costs. (Will the US participation in the Canadian search cause difficulties here?) What does seem to be lacking is a proper notification procedure, both of spacecraft in distress and spacecraft carrying potentially hazardous material. It would presumably not be impossible to extend the treaty banning nuclear weapons from orbit to nuclear fuel units, or failing an outright ban, to make all such "nuclear" launches notifiable to some central authority. Secretary of State Jamieson and Prime Minister Trudeau have already been discussing possible international talks on the problems arising from the aftermath of Kosmos-954. If these should be forthcoming and fruitful, one could well agree with Pravda that this unfortunate incident has, after all, turned out a triumph for detente.

Vera Rich

\section{NSF encourages more university/ industry collaboration}

IN a move carefully timed to coincide with the opening of Congressional hearings on its budget application for the year 1979, Dr Richard Atkinson, director of the US National Science Foundation, announced last week that the foundation plans a major expansion of its support for research projects carried out by joint university/industry groups.

No new funds are to be allocated in the NSF budget for such projects: they will be required to compete for support with other regular grants' applications. 